\title{
A Case of Potential Inborn Error of Metabolism as a Cause of Young Onset Psychosis
}

\author{
Mohd Amiruddin Mohd Kassim ${ }^{1}$, Nicholas Tze Ping Pang ${ }^{1}$, \\ Muhammad Haniff Abdullah², Norharlina Bahar ${ }^{2}$ \\ ${ }^{1}$ Faculty of Medicine and Health Sciences, Universiti Malaysia, Sabah, Jalan UMS, Kota \\ Kinabalu, Malaysia, '² Department of Psychiatry, Hospital Selayang, Selayang, Selangor, \\ Malaysia
}

\begin{abstract}
Introduction: Young onset psychosis has poor prognosis, and inborn errors of metabolism (IEM) can be easily missed. There is scarce information regarding IEM and young onset psychosis in Malaysia. Case Report: A 15-year-old Malay girl presented at the age of 8 years with a history of intellectual disability and neuro-regression, subsequently developing psychotic and obsessive-compulsive symptoms several years later. Organic workup revealed elevated lactate levels. Urine organic acid chromatogram revealed a moderate peak of lactate however most other investigations were normal. As MRI brain is normal and there are no neurological signs it appears less likely there is an underlying IEM-related aetiology for psychosis. Discussion: Various IEMs can be related to psychosis however the incidence is very low and quality of evidence is poor. Thus, any psychiatric presentation, particularly with suggestive clinical signs, should warrant an organic (including IEM) workup since these causes are potentially reversible with supplementation.
\end{abstract}

Keywords: psychosis; inborn error of metabolism; organic

Copyright (C) 2021 KBCSM, Zagreb

e-mail: apr.kbcsm@gmail.com • www.http://apr.kbcsm.hr

\section{Introduction}

Young onset psychosis has a very poor prognosis [1], correlated with higher social disability scores [2]. However, any associated atypical or organic symptoms should prompt a search for organic aetiologies. This case report discusses a rare but interesting possibility of psychosis secondary to an inborn error of metabolism (IEM). It also aims to supplement scarce information regarding IEM and young

Correspondence to: Nicholas Tze Ping Pang

Faculty of Medicine and Health Sciences

Universiti Malaysia Sabah, Jalan UMS

Kota Kinabalu, Malaysia

Telephone: + 6016-881 4058

E-mail: nicholas@ums.edu.my onset psychosis, as it is scant both in the Malaysian setting and in the world.

\section{Case Report}

Ms NZ is a 15-year-old Malay girl who initially presented aged eight as a referral from a general practitioner to a psychiatrist. She presented with increasingly poor academic progress that year, accompanied by new onset setbacks in ability to read and write, which were also associated with hyperactivity and inattention, especially noticeable in school. According to history elicited from her parents, prior to the age of eight, she was able to construct ageappropriate sentences and was able to perform all activities of daily living including feeding, toileting, and self-care. Her gross and fine mo- 
tor skills prior to the age of 8 had been slightly delayed, but she had been able to attend conventional kindergarten previously without being referred to special education, and she had previously exhibited appropriate social cognitions at pre-school. In terms of cognitive abilities, she was able to draw up to age prior to the age of eight. In terms of reading and writing, she was able to recognise words and write sentences, albeit a little slowly, but it had not been grossly impaired previously.

A year later, she became increasingly paranoid and felt she was being watched. Her paranoia extended to small animals e.g. cats and the sounds of vacuum cleaners. She was thus frequently anxious and worried resulting in school refusal. There were no perceptual abnormalities, seizures, abnormal movements or self-mutilations.

Over the subsequent 3 years, she showed signs of neuro-regression. She was previously toilet trained but started soiling herself. She also could not manage activities of daily living e.g. bathing, changing clothes etc, where previously she was able. Her writing deteriorated and became unrecognizable. She walked holding on to walls and furniture and her movements became slow. Otherwise, there were no depressive or manic symptoms noted. Her parents are unrelated and there is no similar family history. Birth history was unremarkable and there were no antenatal or postnatal difficulties or childhood infections. There was slight delay in speech and gross motor development.

Physical examination revealed a well-nourished child who was not dysmorphic. She had hyperpigmented streaks on her trunk and limbs, which followed Blaschko lines. Her gait was slow and careful but not broad based nor ataxic. Examinations of other systems were normal. Thyroid function tests, full blood counts, renal and liver functions were normal. She was diagnosed as intellectual disability with psychosis based on clinical picture; an IQ test was not performed at that time by the treating team as she exhibited gross deficiencies. She was commenced on quetiapine and it resulted in an improvement of her movements.

A year later, she began demonstrating wellformed auditory hallucinations and strong persecutory delusions. Speech was also increasingly disorganised with use of neologisms and echolalia. There was no thought alienation or any perceptual disturbances in other modalities. Repetitive behaviours also evolved, related to checking water pipes, frequently washing her hands, not eating certain kinds of food and changing clothes repetitively. Her diagnosis was revised to schizophrenia with obsessive-compulsive symptoms and underlying intellectual disability. She was trialled on multiple antipsychotics, but was sensitive to many (olanzapine, risperidone, haloperidol, and chlorpromazine). She developed multiple extrapyramidal side effects to risperidone, haloperidol, and chlorpromazine on low doses, including dystonia and akathisia, and developed metabolic syndrome while on olanzapine.

Her behaviour became increasingly unmanageable, warranting a week of hospitalisation. Despite augmentation of quetiapine with aripiprazole, sodium valproate, and escitalopram, her symptoms appeared to be poorly controlled. Moreover, her behaviour remained difficult, with tantrums and sudden episodes of verbal aggression. Upon further investigating her young-onset psychosis, MRI Brain was normal. However, incidentally her lactate was elevated $(5.8 \mathrm{mmol} / \mathrm{L})$, with a mildly elevated Alanine (592 umol/L) and Glycine (307 umol/L). With further help from the genetics team, urine organic acid chromatogram revealed a moderate peak of lactate, with a small but significant peak of glycolate and oxalate. No diagnostic pattern could be inferred. Most secondary screenings were normal (Table 1). 
Table 1. Results of performed investigations

\begin{tabular}{|c|c|c|}
\hline Investigation & Result & Normal Values \\
\hline $\begin{array}{l}\text { OTC (Ornithine Carbamoyltransferase) } \\
\text { Gene Testing }\end{array}$ & No mutation detected & \\
\hline LSD (Lysosyme Storage Disease) Screening & All negative & \\
\hline Urine Mucopolysaccharides & Normal & \\
\hline Serum copper & Normal & $11-22 \mathrm{umol} / \mathrm{L}$ \\
\hline Ceruloplasmin & Normal & $\begin{array}{l}\text { Male: } 0.15-0.30 \mathrm{~g} / \mathrm{L} \\
\text { Female: } 0.16-0.45 \mathrm{~g} / \mathrm{L}\end{array}$ \\
\hline Ammonia & Normal & $\begin{array}{l}\text { Male: } 16-60 \mathrm{umol} / \mathrm{L} \\
\text { Female: } 11-51 \mathrm{umol} / \mathrm{L}\end{array}$ \\
\hline $\begin{array}{l}\text { Phytanic acid/VLC (Very Long Chain) } \\
\text { fatty acid }\end{array}$ & Normal & $<0.2 \mathrm{mg} / \mathrm{dL}$ \\
\hline Congenital disorder of glycosylation screen & Normal & \\
\hline $\begin{array}{l}\text { Orotic, uracil, pseudourine, hypoxanthine, } \\
\text { xanthine, thymine }\end{array}$ & Normal & $\begin{array}{l}\text { Orotic: }<2 \mathrm{nmol} / \mathrm{mL} \\
\text { Uracil: }<2 \mathrm{nmol} / \mathrm{mL} \\
\text { Hypoxanthine: }<15 \mathrm{nmol} / \mathrm{mL} \\
\text { Xanthine: }<6 \mathrm{nmol} / \mathrm{mL} \\
\text { Thymine: }<2 \mathrm{nmol} / \mathrm{mL}\end{array}$ \\
\hline Uric acid & 789 (Mildly elevated) & $150-500 \mathrm{umol} / \mathrm{L}$ \\
\hline Lactate & $5.8 \mathrm{mmol} / \mathrm{L}$ (High) & $<2.2 \mathrm{mmol} / \mathrm{L}$ \\
\hline Plasma amino acids & $\begin{array}{l}\text { Non-specific elevation of } \\
\text { glutamate and ornithine } \\
\text { Low levels of methionine, } \\
\text { leucine, phenylalanine, few } \\
\text { EFA (most likely due to } \\
\text { poor oral intake }\end{array}$ & $\begin{array}{l}\text { Glutamate: } 32-140 \mathrm{umol} / \mathrm{L} \\
\text { Ornithine: } 44-90 \mathrm{umol} / \mathrm{L} \\
\text { Methionine: } 13-30 \mathrm{umol} / \mathrm{L} \\
\text { Leucine: } 70 \text { - } 170 \mathrm{umol} / \mathrm{L} \\
\text { Phenylalanine: } 26-86 \mathrm{umol} / \mathrm{L}\end{array}$ \\
\hline
\end{tabular}

Juvenile metachromatic leukodystrophy needed to be ruled out as it occasionally presents with behavioural changes and psychosis before mental deterioration. However, this diagnosis is usually accompanied by MRI changes. EEG testing was therefore arranged to investigate for other causes.

\section{Discussion}

The overall incidence of IEMs has been estimated to be approximately 40 cases per 100,000 live births [3]. A number of adultonset IEMs are associated with psychosis: homocysteine metabolism diseases, urea cycle disorders, porphyria, Wilson disease, cerebrotendinous xanthomatosis and NiemannPick disease type C [4]. A pioneering 2014 
systematic review demonstrated evidence regarding prevalence of psychosis in IEMs was of poor quality due to their rarity; only 611 cases were identified in the literature review stretching from 1967-2012 [5]. Sedel and associates (2007) presented an alternative tripartite IEM classification according to psychiatric signs at onset. Group 1 present with emergencies, manifesting with recurrent bouts of confusion. Group 2 IEMs are associated with chronic psychiatric symptoms arising in adolescence. Group 3 contains IEMs presenting as mild mental retardation and late-onset behavioural or personality changes [4].

Ms NZ's changes appear to fall more into Group 2 IEMs. This group includes homocystinuria [6], Wilson disease [7], adrenoleukodystrophy [8] and some lysosomal disorders [9]. In the case of Ms NZ, Wilson's is excluded by clinical findings and copper/ceruloplasmin results, whereas leukodystrophy is usually accompanied by MRI evidence. There is no characteristic elevation of methionine and no presence of homocysteine that should be present in a homocystinuria. In addition, a solely raised lactate level is not suggestive of any IEM related to a psychiatric presentation. However, there are associations between elevated lactate levels and schizophrenia, both in post-mortem and pre-clinical settings $[10,11]$. There is also increasingly robust evidence suggesting lactate related abnormalities may underpin cognitive dysfunction as well [12]. Recent evidence from domiciliary settings also

\section{References}

1. Davidson L, McGlashan TH. The varied outcomes of schizophrenia. Can J Psychiatry. 1997;42:34-43.

2. Eggers C, Bunk D. The long-term course of childhoodonset schizophrenia: a 42-year followup. Schizophr Bull. 1997;23:105-17. suggest extant relationships between lactate levels and intellectual disability [13].

A general diagnostic strategy is suggested in these cases $[13,14]$. IEMs are usually suspected where there is a family history; if there are clinical signs triggered by conditions involving increased protein catabolism, e.g. fever, food intake, surgery or prolonged fasting; or if there are signs of a possibly more diffuse clinical picture. This includes neurological signs of cognitive and motor dysfunction, as well as systemic signs, e.g. skin, ophthalmological and visceral signs.

\section{Conclusion}

The lack of dysmorphia, organomegaly and neurological signs coupled with a normal MRI brain mean the lactate finding is most probably not related to an IEM in this case. Nevertheless, this is a reminder that any psychiatric presentation, particularly with any family history or suggestive clinical signs, can be linked to a rare IEM, especially since some of these causes are potentially reversible with supplementation.

\section{Conflict of Interest}

None to declare.

\section{Funding Sources}

None to declare
3. Applegarth DA, Toone JR, Lowry RB. Incidence of inborn errors of metabolism in British Columbia, 19691996. Pediatrics. 2000;105:e10.

4. Sedel F, Baumann N, Turpin JC, Lyon-Caen O, Saudubray JM, Cohen D. Psychiatric manifestations revealing inborn errors of metabolism in adolescents and adults. J Inherit Metab Dis. 2007;30:631-41. 
5. Bonnot $\mathrm{O}$, Klünemann $\mathrm{HH}$, Sedel F, Tordjman S, Cohen D, Walterfang M. Diagnostic and treatment implications of psychosis secondary to treatable metabolic disorders in adults: a systematic review. Orphanet J Rare Dis. 2014;9:65

6. Abbott MH, Folstein SE, Abbey H, Pyeritz RE. Psychiatric manifestations of homocystinuria due to cystathionine $\beta$-synthase deficiency: Prevalence, natural history, and relationship to neurologic impairment and vitamin B6-responsiveness. Am J Med Genet. 198;26:959-69.

7. Dening TR, Berrios GE. Wilson's disease: psychiatric symptoms in 195 cases. Arch Gen Psychiatry. 1989;46:1126-34.

8. Rauschka H, Colsch B, Baumann N, Wevers R, Schmidbauer M, Krammer M, et al. Late-onset metachromatic leukodystrophy genotype strongly influences phenotype. Neurology. 2006;67:859-63.

9. Bedilu R, Nummy KA, Cooper A, Wevers R, Smeitink $\mathrm{J}$, Kleijer WJ, et al. Variable clinical presentation of lysosomal $\beta$-mannosidosis in patients with null mutations. Mol Genet Metab. 2002;77:282-90.

10. Rowland LM, Pradhan S, Korenic S, Wijtenburg SA, Hong LE, Edden RA, et al. Elevated brain lactate in schizophrenia: a $7 \mathrm{~T}$ magnetic resonance spectroscopy study. Transl Psychiatry. 2016;6:e967.

11. Fukushima T, Iizuka H, Yokota A, Suzuki T, Ohno C, Kono Y, et al. Quantitative analyses of schizophreniaassociated metabolites in serum: serum D-lactate levels are negatively correlated with gamma-glutamylcysteine in medicated schizophrenia patients. PLoS One. 2014;9:e101652.

12. Sullivan CR, Mielnik CA, Funk A, O'Donovan SM, Bentea E, Pletnikov M, et al. Measurement of lactate levels in postmortem brain, iPSCs, and animal models of schizophrenia. Sci Rep. 2019;9:5087.

13. Sengupta A, Das U, Manna K, Biswas S, Datta S, Khan A, et al. An association study of severity of intellectual disability with peripheral biomarkers of disabled children in a rehabilitation home, Kolkata, India. Sci Rep. 2019;9:1-14.

14. Saudubray JM, De Guerre I, Sedel F, Charpentier C. A clinical approach to inherited metabolic disorders. In: Saudubray JM, van den Berghe G, Walter J, eds. Inborn Metabolic Diseases: Diagnosis and Treatment. Berlin: Springer-Verlag; 2006. p.3-48.

\section{Slučaj potencijalne prirođene greške metabolizma kao uzroka psihoze s ranim početkom}

Sažetak - Uvod: Psihoza ranog početka ima lošu prognozu, a prirođene greške metabolizma (PGM) mogu se lako previdjeti. Informacije o PGM-u i psihozi kod mladih u Maleziji su oskudne. Prikaz slučaja: Petnaestogodišnja Malezijska djevojčica prezentirala se u dobi od 8 godina s poviješću intelektualnog invaliditeta i neuroregresije, nakon čega su se nekoliko godina kasnije razvili psihotični i opsesivno-kompulzivni simptomi. Organska obrada otkrila je povišenu razinu laktata. Kromatogram organske kiseline u urinu otkrio je umjereni porast laktata, no većina ostalih nalaza bila je u granicama normale. Kako je MRI mozga bio uredan i nije bilo neuroloških ispada, čini se manje vjerojatnim da je u podlozi psihoze bila PGM kao etiološki čimbenik. Rasprava: Različite PGM mogu se povezati s psihozom, ali učestalost je vrlo niska, a kvaliteta dokaza loša. Stoga bi svaka psihijatrijska klinička slika, posebno sa sugestivnim kliničkim znakovima, trebala uključiti organsku obradu (uključujući PGM) jer su ti uzroci potencijalno reverzibilni upotrebom suplemenata.

Ključne riječi: psihoza; urođena pogreška metabolizma; organski 
